\title{
TOWARDS MORE COMMUNITY-ORIENTED AND Collaborative PlanNing for Alaska Native VILLAGES
}

\author{
E. Barrett Ristroph \\ Ristroph Law, Planning, and Research $1298^{\text {th }}$ Avenue, Fairbanks, Alaska 99701, USA
}

\begin{abstract}
Based on reviews of existing plans as well as interviews and conversations with 153 people that live in Alaska Native Villages (ANVs) or influence ANVs plans and policies, this article describes how planning for climate change adaptation and hazard mitigation takes place and provides suggestions for improvement. Planning processes are generally initiated and overseen by outside entities and have limited community participation, as they are disconnected from community events and activities. A more participatory approach that engages ANV residents by building on existing indigenous community practices may be more helpful in developing a common vision for adaptation. Planners could improve planning by spending more time talking to community members, and if desired by ANVs mentoring leadership to better engage in the process and assisting with dispute resolution. ANVs could improve planning by providing for activities that foster connectivity and a common vision and supporting efforts to build community leadership.
\end{abstract}

\section{KEYWORDS}

Collaborative planning; indigenous planning; social capital; climate change adaptation; Alaska Native Villages

\section{INTRODUCTION}

Many indigenous communities have a history of externally driven planning processes, which are initiated and guided by a private or government planning entity not based in the community. Problems with externally driven processes relate to paternalistic planning approaches that disregard indigenous knowledge, cultural goals, planning traditions, and concepts of space[1, 2, 3, $4,5,6]$. Such approaches can perpetuate outside intervention and control, entrenching disparities and repressing tribal capacity $[7,8,9]$. Further, there is a lack of indigenous planners or attention to indigenous issues in the planning field $[1,3]$.Finally, even where planning efforts attempt to avoid these problems; they fail to address the legacy of post-settler states' usurpation of indigenous land rights [1].

As much as there is a desire for indigenous planning to be self-contained [9, 10], small, rural indigenous communities grappling with extreme challenges like climate change may continue to rely on external planning assistance $[11,12,13]$. In this article, I consider how externally led planning efforts have served Alaska Native Villages (ANVs) in addressing natural hazards and climate change. ANVs are nationally recognized tribes that are typically small, rural communities. Many are grappling with changes in flooding and erosion, changes to the species on which they subsist, melting permafrost and later formation of ice along their shores each fall-ice that used to serve as a protective barrier from destructive fall storms [14, 15, 16]. I suggest that a more community-oriented planning approach and other efforts to foster social connections within and beyond an ANV may be more helpful than a plan developed solely by outside entities.

DOI : 10.5121/civej.2018.5401 


\section{METHODS}

My methods aimed to capture planning processes related to climate change and natural hazards for a diversity of ANVs across the State of Alaska. Within a total of 229 ANVs, there are at least 11 distinct cultural groups of indigenous peoples and at least 20 different languages across the state [17]. Only about two dozen ANVs are connected to the Alaska road system, while the rest are not accessible by roads. A small handful directly benefit from oil development income, while around three dozen still have no running water in the homes. There are different percentages of people who self-identify as Alaska Natives within different ANVs, ranging from less than $10 \%$ to nearly $100 \%$. In addition, the type of local government varies. Seventy ANVs have no city or county-level government at all and are led by a tribal council. An additional thirty or so lack a city-level government but are part of a county-level government (known as a borough). Others have a city-level government in addition to their tribal councils. Among those with city-level governments, some are also part of boroughs. [18].

\subsection{Interviews}

I reached out to almost all the ANVs across the State of Alaska to explain the nature of my research and obtain recommendations for knowledgeable residents to participate in my study. I had interviews and interview-like conversations with residents until I felt that I had a sample representing the diversity of ANVs across Alaska, and I was not getting any new information. This resulted in interviews or interview-like conversations (for those that did not wish to be formally interviewed) with 76 people from 59 ANVs. Figure 1 shows the ANVs from which participants came. Participants included people from communities that differed in terms of ethnicity (type of Alaska Native and percentage of Alaska Native residents relative to non-Native residents); geography (riverine or coastal; Arctic, interior, west coast, Aleutians, south central, and southeast); connection to Alaska's road system; political system (presence of incorporated city, location within an incorporated borough); wealth; experience with flooding and erosion disaster declarations; relocation status; and experience with planning (some ANVs had no plans, while others had numerous types of plans).

To better understand adaptation strategies,barriers, and planning efforts from the perspective of those outside ANVs, I had interviews or conversations with 77 individuals associated with entities outside of ANVs. I first identified representatives from the agencies that play a role in ANV adaptation to climate change, making a chart of key state and federal agencies, laws, and programs authorized by the relevant laws. From there I identified additional interviewees using a "snowball" technique, where I got recommendations from previous interviewees for additional participants $[19,20,21]$. These included not only representatives from agencies, but also representatives from the state and national legislature, Alaska Native non-profit entities, and lawyers and planners who worked with ANVs. 
Civil Engineering and Urban Planning: An International Journal (CiVEJ) Vol.5, No.2/3/4, December 2018

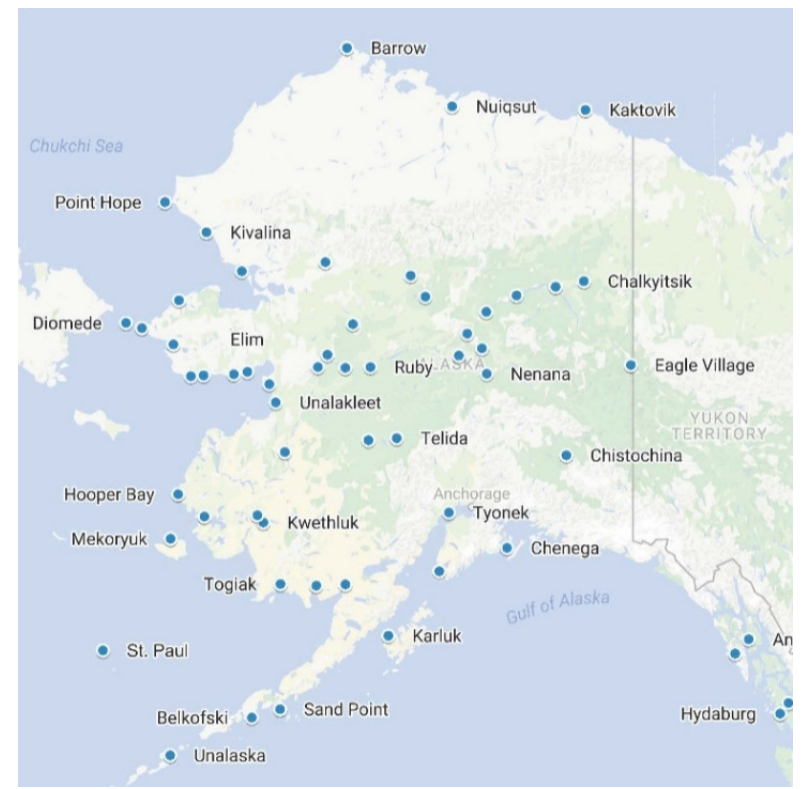

Figure 1: ANVs from which participants came

(Google Maps)

I prepared slightly different questionnaires for ANV residents and those from outside, although both focused on the role of planning, adaptation strategies, adaptation obstacles, the role of communities in planning for and carrying out adaptation, and the role of external assistance.

\subsection{Plans}

Most ANVs that still have residents living at their village sites have some form of written community plan on file with the Alaska Division of Community and Regional Affairs [18].I searched this database for plans written in the last 20 years relevant to the 59 ANVs from which my ANV-based participants came. There were no stand-alone climate change adaptation plans for any of these communities, which forced me to broaden the scope of my review to consider plans dedicated to a range of community challenges. I considered hazard mitigation plans (HMPs), which are relevant to climate-related natural hazards, and other community plans concerning economic development and land use. Of the 59 ANVs, 38 had plans providing for land use and economic development, and 43 had their own HMP or were part of a multi-jurisdictional HMP. Thirty-five ANVs had other types of plans related to economic development, tourism, transportation, relocation, housing, infrastructure, and emergency preparedness. Only four of the 59 ANVs lacked publicly available plans of any kind. Climate change is mentioned in many recent ANV plans: HMPs for 26 ANVs and four other plans refer to climate change as contributing to hazards, while three relatively recent HMPs (from 2015) refer to climate change as a stand-alone hazard. Even where HMPs do not specifically mention climate change, almost all refer to flooding, erosion, and severe storms-key hazards associated with climate change in Alaska [14].

In addition to plans relevant to the 59 ANVs, I reviewed all adaptation plans I could find for ANVs, which included the plan for the Native Village of Shaktoolik [22] and the plan for four tribes based in Nome, Alaska [23]. I did not analyze documents that were essentially reports on climate change impacts rather than plans. 


\subsection{Analysis}

I used qualitative content analysis [24, 25] to identify themes that arose from interviews and those conversations that covered interview questions, as well as in ANV plans. Themes arose deductively from the questions I asked in my interviews as well as inductively from new themes raised by participants $[20,25,26] . I$ created two case-by-variable matrix where each row corresponded to an individual participant or an ANV plan, and each column corresponded to a theme or variable.

For interview participants, variables included identifying characteristics (i.e., age, gender, race). Initial themes included views on the role of planning in preparing for climate change, adaptation and relocation strategies, and views on the role of the village itself in addressing climate change compared to that of external entities. New themes included views on race, colonization, community relationships, and community challenges not related to climate change. For plans, variables included the year of the plan, the type of problems (i.e., climate change impacts) it discussed, who prepared the plan, and what strategies were suggested.

I initially planned to triangulate themes in plans with those expressed by participants, but this proved unworkable due to the disconnection between what participants expressed about their communities and what I found in the plans. Further, differences in the questions and themes each participant chose to discuss limited my ability to quantitatively compare responses between different participants. Given this limitation and the subjectivity of my coding, I decided that using statistical analysis was not appropriate [20,27]. I thus avoid referring to specific numbers of participants, except to give the reader a general sense of how many participants provided a similar comment. To give an order of magnitude of the responses I got, I refer to "a few" (about 2 to 5), "several" (about 6 to 10), "a number of" (11-30), or "many" (more than 30). These categorizations are not statistically significant and should not be interpreted in that manner.

For purposes of this article, there are a few instances where I have supplemented my research findings with my experience as a lawyer and planner for the North Slope Borough, a county-level government in Arctic Alaska (2007 to 2011), and for the ANVs of Allakaket (2016 to 2018) and Newtok (2017 to 2018). Additional information regarding methods is available in Ristroph [28].

\section{Literature On Building Better Planning Processes}

\subsection{Collaborative Planning and Social Capital}

The collaborative planning literature provides insight on how planning might better harness the resources of external entities as well as those of the community. Collaborative planning generally requires a process of consensus building between participants who have roughly equal authority in the collaboration and are committed to working together [29, 30, 31, 32, 33]. Particularly with indigenous groups, planning processes need to recognize community knowledge and values alongside Western science [34, 35].

Generally, planning collaborations are more effective if social connections and trust are already present among the participants or are formed during the process [36, 37, 38, 39, 40, 41]. There is an entire body of literature on the formation and importance of these connections and trust, known as "social capital" [42, 43, 44]. Social capital theory explains how individuals use their connections for their own and for the collective good [42]. Aside from facilitating planning processes, social capital can boost community resilience in the face of climate change $[45,46,47$, 48, 49] and establish a basis for the kinds of collective action needed for community adaptation 
$[30,35,42,46,50,51,52]$. The importance of social capital has been noted in the context of ANV adaptation $[35,53,54]$, but has received less attention in regards to ANV planning.

In order to be heard by external government agencies and obtain resources needed for adaptation, connections between indigenous communities and external entities (known as "linking" social capital) are important $[4,55]$. Building this capital can be a challenging given the legacy of colonization and the power imbalance between indigenous participants and external agents [3, 8 , 56].In addition to connections with external agents, connections within ANVs (known as "bonding" social capital) are important to enable a community to act with a common vision [54, 57]. Strong and respected leaders are often essential in fostering and implementing this vision among stakeholders [37, 58, 59].

Beyond building social capital, there is a need for planning processes to better account for existing decision-making structures, local leaders, and cultural practices [60, 61, 62]. Planning can be oriented around cultural events and supported by community and elder knowledge [4, 9, 63].Rather than simply relying on public planning meetings in an official setting, planners can take a more flexible approach that fosters conversation with community members when and where they are available $[21,64]$.

\subsection{Challenges Specific to ANV Planning}

Building a common vision within an ANV can be challenging due to weak bonding social capital in some communities, which may relate to disputes between different families or entities. This issue has received limited attention in the literature on ANVs (with the exception of Brunner and Lynch [65] but has been noted in reports [66] and news articles [67, 68]. Several historical and political factors may explain these disputes. First, an ANV is not always a single indigenous people. ANVs have often formed from different clans or bands that came together in a single settlement [18].

Second, Western law has created political divisions. The Alaska Native Claims Settlement Actor ANCSA (43 U.S.C. $\S \S 1603,1606,1607$ ) has led to three different spheres of power in most ANVs: the tribal government, the city government, and the village corporation leadership [16, 69]. The tribal government has no jurisdiction over land, only over tribal members. It is often the receiving entity for federal grants for health, housing, and roads. Many but not all ANVs are associated with an incorporated city, which is a political subdivision of the state that may receive some grants for community development. The city council may consist of non-Native members elected by residents, while the tribal council consists entirely of Native residents. Some communities have leadership challenges when the tribal council and the city government do not agree on (or even talk about) matters of mutual concern [69].

In addition to the tribe and city, most ANVs are associated with a third entity-the village corporation-which often owns most of the land in and around the village. If the village is in a resource-rich area, the village corporation may drive development of a lands important to the tribe [70], and it may have an office and business outside of the village [16]. Not all tribal members within an ANV are necessarily shareholders of the village corporation, and a number of shareholders live outside of the ANV [16].This can lead to political differences between the tribe and corporation.

Beyond bonding social capital, there are challenges to building linking social capital with outside entities that could provide assistance. ANVs are typically remote and rural, far from urban-based state and federal decision-makers [54]. Agencies in Alaska have traditionally not incentivized 
relationship-building between employees and communities, and most employees do not stay at one post where they work with the same communities year after year [21]. Some rural communities and individuals may feel that they have no control over government decisions it or that their voice will not be heard [71].

Despite the obstacles to linking social capital, ANV planning will likely continue to rely on outsiders for several reasons. First, due to ANCSA, ANVs lack jurisdiction over their traditional lands and natural resources (see 43 U.S.C. \$1603),such that they must cooperate with local, state, and federal entities regarding land use or game management. Second, ANVs are often small and impoverished communities without their own tax base, such that they lack staff to draft plans for technical issues such as climate change[18]. Third, climate change in Alaska is occurring much more rapidly than elsewhere in the United States, threatening the continued physical existence of some ANVs [14, 15, 72].Even if ANVs had the means to draft plans, they often lack the resources needed to carry out large-scale adaptation measures such as relocation [55].

\section{KEY Findings On Adaptation And Hazard Mitigation Planning Processes In ANVS}

This section outlines how ANV planning may have traditionally taken place, attitudes of ANV participants toward current planning processes, and weaknesses of these processes. Findings regarding the nature and quality of the plans themselves are discussed elsewhere [73].

\subsection{Internal ANV Planning}

Consistent with the literature on indigenous planning [4, 7, 63], there is some tradition of "indigenous" planning within ANVs that may differ from what is expressed in the plans I reviewed. Based on my review of community histories, I presume that some form of communitylevel planning or a common vision facilitated past community relocations in response to flooding [18].But this kind of planning was likely unwritten and consensus-based. Several participants referred to unwritten understandings in modern times about what a community would do in the event of a disaster. Two from the same coastal community referred to an understanding that their community would move as far inland as needed, with guidance from elders.

A few participants, all older Native men, referred to their indigenous planning history. One older Native man originally from a southwesternAlaska village said, "We're the best planners in the world. We plan...because we have to." Another participant (an urban-based non-Native researcher) said that planning has traditionally occurred on a family level (i.e., preparing for a memorial potlatch celebration) rather than at a community level. An older Native man from a northeast Alaska village contrasted traditional planning with modern planning, "Families plan based on their own situations. Community planning can take responsibility away from people. People will give away their responsibility to a planning contractor."

As the latter quote suggests, I found a gap between the kind of planning that traditionally facilitated adaptation by Alaska Native families and clans, and the Western-style planning that is broadly occurring across Alaska. For the rest of this section, I show that the current style of planning, while praised by some outside of ANVs, does not really fulfill the needs and values of ANVs. 


\subsection{Ambivalence toward Planning}

In this subsection, I outline the range of viewpoints shared by nearly three quarters of all participants on the utility of planning, and I highlight the differences between those in ANVs and those outside. Nearly half of those who shared views (nearly three eighths of all participants) made ambivalent statements about planning, with nearly half of the ambivalent views coming from ANV participants. Nearly half who shared views (with a slight majority in ANVs) described plans as useful, while several (almost all in ANVs) expressed serious doubts about the value of the planning that has occurred for their communities.

About half of all participants (including some who were ambivalent on the utility of planning) referred to beneficial aspects of plans. Many offered reasons frequently cited in the literature for planning: preparing for emergencies and hazards and guiding future growth and development. A number of participants noted the importance of plans in guiding community relocation and determining which land would be suitable for settlement. But the primary benefit of planning expressed by participants was to show outside entities what an ANV wants so it could get funding. This response was provided by about half of those who described benefits of planning, with a slight majority in ANVs.

A number of participants (but only one in an ANV) suggested that the process of planning is helpful even if the plan is not, because the process can be useful for networking and collaborating. As one non-Native federal agency representative said, "Planning is essential even if plans are useless." A non-Native state agency representative suggested that, "The hazard mitigation plan is super valuable because of the process of going through it." Those who made such positive statements generally did not acknowledge problems with plan quality or implementation.

About a quarter of those who discussed the utility of planning (with a slight majority in ANVs) offered criticisms of planning. An older Native man from an eastern interior village explained, "Planning is just a buzzword. It doesn't have any practical application out there where we're from." A few felt that, now that so much infrastructure has been put in place throughout rural Alaska, it is too late for planning. An older Native man from interior Alaska said,

Planning should have been done in 1980s and 1990s, at this point it is moot. The question is how much will it cost to deal with it, not how to plan to deal with it. It's like when your car breaks down, you don't plan to fix it, you hope someone is around that can fix that particular car. The problem is that the infrastructure in rural Alaska is old and people can't fix it, it's too outdated.

A few said that there were too many uncertainties to plan. Several (mostly in ANVs) said that Western-style planning did not match with traditional planning or did not take into account tribal concerns. A number (mostly outside of ANVs) expressed a sense that there are too many plans and studies, and not enough action. A few (mostly in ANVs) said people didn't have time to look at plans, so they weren't used.

To summarize, those outside ANVs tend to see planning as being more useful than those within ANVs who are stuck with plans that may not reflect their communities' true needs, values, and traditions. In the following subsections, I highlight the particular problems with ANV planning processes. 


\subsection{Limited Community Participation}

Based on my conversations with participants and my review of community plans, I found that planning for ANVs is generally initiated, led, and may be carried out by people outside of ANVs. No plan that I reviewed was developed solely by an ANV. Hazard mitigation plans (HMPs) are done by contractors for the State of Alaska's Division of Homeland Security who ensure that the plans conform to specific federal regulations (44 C.F.R. $\S$ 201.6). Other planning processes (outside of HMPs) may be less formal, yet no less externally driven. For example, "comprehensive" or "local economic development" plans may be initiated by regional Native non-profit entities, whose staff complete the plans based on a standard template. Alternatively, for ANVs situated within a borough, plans may be initiated by the borough and completed by contractors.

A number of ANV participants were unaware that their communities had written plans. Only a few referred to their communities' HMPs, though HMPs are in place for 43 of the ANVs from which participants came. Often only a small segment of the community comes to planning meetings and is engaged in the planning process. One community leader, a Native woman from a northern Alaska village, acknowledged the need for getting "the whole community to be working on a plan," but said, "It's hard to get the whole community involved. Community meetings work well in smaller communities. In larger communities, only the people really interested will go." An urban-based non-Native planning consultant described attendance at an ANV planning meeting he coordinated as follows: "During the consultant's first visit to [the community] for this project, it became clear that most residents did not attend public meetings." While this could be said for many communities, it is noteworthy because the community in question is small (a few hundred people) with little in the way of employment or entertainment options to otherwise occupy residents.

It may be that people are simply involved in their own lives and do not get sufficient benefits from public meetings to warrant coming. A few ANV participants specifically referred to a sense of fatigue with meetings and research led by outsiders. Yet, based on my review of HMPs, contractors rely on public meetings (sometimes only with teleconference participation) and newsletters rather than more personal engagement. This meets FEMA's public involvement standard, which does not even require any sort of meeting (44 CFR $\S 201.6(\mathrm{~b})$ ). As non-Native urban planner that worked on HMPs told me, "The contractors that write these plans end up (myself included) writing them without too much input from village. There's public input requirement, you have to let them know you're writing the plan during the drafting process; then you have to have them review the final draft, but that's it."

A few participants and plans offered strategies for achieving better input. The aforementioned contractor told me that he was able to get more information by having smaller group meetings as well as surveys. The community leader from northern Alaska quoted above suggested,

There's a need to bring in all the organizations in the community. Use mailers and word of mouth. It might help to do this outside as a summer barbecue. If you get all the organizations involved, they will tell their employees, who will tell their families. Then this town becomes a little smaller. Use the right wordsword will get around in about an hour.

A number of people specifically called for planners and researchers to listen to elders and not disregard their traditional knowledge. Nearly half of all my research participants (most of whom were Native and/or in ANVs) talked about the role of this knowledge in adaptation, with the 
majority describing it as useful. Nearly an eighth of all participants (mostly Native and/or in ANVs) expressed frustration that this knowledge is not considered on par with Western science in decision-making and planning.

On the other end of the spectrum, several participants, mostly in ANVs, suggested that youth should be more involved in planning and other climate change adaptation actions. The Kwethluk community plan provides an example of how this involvement could occur: planners held meetings with high school classes and asked students to list their likes and dislikes about the community, offer ideas on how the dislikes could be changed, and then select their top three priorities from the list of ideas (The Arcturus Group 1998). This information was shared at the plan development work sessions and incorporated into the community needs section of the plan.

Beyond embracing tactics to improve planning participation, however, there is a need to address the underlying impediments to achieving a common vision. As detailed in the next two subsections, there are impediments related to linking and bonding social capital.

\subsection{Need for Linking Social Capital to Improve Collaboration and Plan Implementation}

As discussed in Subsection 3.2, there is a need for stronger connections between a community and those outside of the community that are in a position to collaborate and provide resources (linking social capital). A number of participants (with the majority in ANVs) referred to a lack of communication or cooperation between ANVs and outside government as an impediment to implementing adaptation strategies. Participants talked about poor information sharing and communication between the community and outside entities that are not aware of what is happening "on the ground." One ANV resident from western Alaska described state and federal agency biologists as "computer biologists." He said, "They need to feel the pulse of what's happening-numbers on the computer don't tell that much."

The sheer size and high price tag of travel in Alaska impede relationship-building between agencies and ANVs. Limited agency budgets mean limited trips to ANVs. When trips occur, they are short. Opportunity for meaningful conversation is limited. As a representative from a Department of Interior Landscape Conservation Cooperative (LCC) explained, "The challenge for the LCC is that it works with 68 tribes and 17 First Nations, most of whom are off road, and there are only two full-time staff. So they can't go into villages and make face-to-face relationships. They know face-to-face is the way to do co-management, but they can't do it regularly." While in this example the issue was co-management of game, the problem of limited time in communities also applies to collaborative planning.

Another problem in building rapport with external entities is that there are some still language barriers in Alaska, particularly with elders in remote areas. An Interior Alaska elder said that agencies who visit his village tended to talk with younger people, not elders, because it is easier for agencies to communicate with people whose first language is English. This reduces the likelihood that traditional community knowledge will find its way into plans.

About a quarter of all participants (mostly in ANVs) offered suggestions for ANVs to build relationships with external entities. Strategies included having an advocate or village liaison to interface with external entities; educating and re-educating new government officials about ANV challenges, participating in regular inter-agency meetings; showing external entities that the ANV has the capacity and willingness to contribute to its own adaptation; and getting publicity through bringing in media and agency representatives for tours or attending conferences. One ANV representative, a Native man from southern Alaska, told me, 
Forming a relationship is a good strategy. Taking the time to talk with people about their day before talking about the work that needs to be done helps. ...most of the agency folks I do talk to are more like friends than they are agency staff. A lot of the time they are just doing their jobs and are bound by laws, rules and regulations. We need to understand that as well. Sometimes it is the agency folks being a******s but there are good people out there who are doing the best they can with what they are limited to do.

About a fifth of all participants (with a third of these in ANVs) offered suggestions for external entities to improve their cooperation and communication with ANVs, including providing interpreters or liaisons. A representative from one agency referred me to a Native from a Yupik village (on the southwest coast) that worked for the Bureau of Indian Affairs and other federal agencies. The representative described this person not only as an English-Yupik interpreter, but as someone who made sure communities could understand the bureaucratic process. When I interviewed this interpreter, she explained

Village residents and agency representatives are each intelligent in their own ways but there's a need for someone in the middle who can help them communicate-someone who knows the community well and can be both a translator and an advocate who relays important information. This can't just be any translator, it has to be someone who understands the grant procedures and can explain them. It doesn't have to be someone from the same village, but it should be someone from the same region/language background.

This kind of liaison could be useful in collaborative planning to make sure that information is clearly conveyed to all stakeholders.

Other suggestions for external entities to improve collaboration included requiring governmentto-government consultation in more situations; coordinating meetings among different agencies so they occur together at a time that is convenient for the ANV (or meeting during conferences); spending more time in ANVs building relationships and meeting with all the entities there; increasing cultural sensitivity; and hiring more Native employees.

One non-Native federal agency representative described the importance of having a flexible outlook in spite of being a "bureaucrat": "When I go to public meetings to talk about things, it's easy for me to just go in there and talk like a bureaucrat for a scheduled time on specific points. That doesn't work in Alaska. A meeting scheduled for an hour can last four hours." Such willingness to spend time with the community could improve relationships that are needed for successful collaboration.

\subsection{Need for Bonding Social Capital and Leadership}

More than a fifth of all participants (with half of these in ANVs) cited community disagreement as a barrier to adaptation. This is a significant finding as I did not ask participants about community unity or social capital, yet participants raised this issue twice as often as any other adaptation strategy. One ANV resident from western Alaska put it this way: "People get excited about a project, but years go by and nothing happens. People start squabbling. It's hard to get consensus. People are mad about things that happened a long time ago."

In addition to community disagreement, a number of participants (about half in ANVs) described community leadership problems as impediments to adaptation. For example, participants noted the lack of resident initiative to serve as leaders or take action; lack of support for leaders or 
jealousy from the community; inadequate community representation by leaders; incompetence; corruption; and the inability of leaders to unite the community. Lack of leadership and community connectivity not only hinder planning, but also reduce the likelihood of gaining outside support for community adaptation. A few state and federal agency representatives told me that when a community is in dispute and there is no clear leader, agencies do not want to invest in the community.

Participants offered various strategies for building connections and fostering a common vision at the community level. An important one was regular community meetings-especially between the tribe, city, and corporation - to build togetherness and work through problems. Another approach involves continuing or revitalizing cultural practices, knowledge, or language as a way to build togetherness. One elder Native man from interior Alaska explained, "Eating together is where all of the good feeling and friendship and renewal of life come from, that's why we have potlach." A number of participants (mostly Alaska Natives) stressed the importance of longstanding cultural traditions that had helped Alaska Natives weather tough times in the past, and several suggested learning and practicing traditional skills and lifeways as a means to adapt. In addition to participant remarks on this theme, 28 community plans called for activities to promote culture such as culture camp.

Tony Christianson, the mayor of the southeast ANV of Hydaburg described how his community was able to come together to create an effective comprehensive plan:

We just did a week-long community planning session to prioritize what our issues are in the community and drafted a new 10-year plan for the community. In 2005 we did a 15-year plan and we accomplished everything. We took a week to go back and think about the next 10 years. I think in 10 years we'll be a selfsustaining community.

Christianson's description suggests that the time and effort that community members put into their planning process contributed to its successful implementation. But the community's willingness to work on the plan did not arrive magically through the planning process. Christianson described how Hydaburg (with a population around 400) had worked to build connections among community entities despite the fractured leadership caused by the Alaska Native Claims Settlement Act. Residents formed what they call "the Unified Front" for all the different community entities to work together. Christianson suggested that this has moved them forward compared to similarly sized communities.

Don Charlie, chief of the interior ANV of Nenana, spoke with a similar degree of dignity about his community. He described Nenana's development plan, which had 11 actions items, seven of which had already been accomplished. Like Hydaburg, Nenana has built social connections in the community outside of the planning process. Charlie described the community's quarterly dinners:

We call it Community Safety and Village Pride. People go there and they don't drink, they don't smoke. We have food and door prizes. All the entities are invited, the city, the school, the churches, the corporation, the tribe, and then we each give a report on what we're doing. We have it every three months. I think one of the reasons communities are bickering against each other is that they don't know what this part of town is doing, all they hear is rumors.

The social connections that ANVs like Hydaburg and Nenana have created among themselves outside of the planning process may help foster a common vision and participation in the planning process. This kind of social and cultural capital within an ANV is particularly important 
given the limitations of other kinds of capital (i.e., financial and human resources). Leadership is also important in crafting a common vision, conveying this vision to outside entities involved in planning, and ensuring that plan implementation can occur on ANV terms.

\section{DISCUSSION: Pathways Toward More Effective ANV ADAPTATION PlanNing}

In this section, I suggest ways to improve planning processes so they are more inclusive and better reflect community needs, knowledge, and values. I begin with my finding that the planning process alone-at least the way it is currently occurring-is insufficient to foster the social connections needed to develop a common vision and an implementable plan.

\subsection{Improving Bonding Social Capital Outside of Planning}

It is significant that so many participants outside of ANVs thought that the Western-style planning process itself (regardless of the resulting plan) was helpful to adaptation, yet only one ANV participant expressed this view. To the extent possible, adaptation planning should better mesh with the local social practices and cultural traditions that have contributed to ANV adaptation for millennia in the absence of Western-style planning.

A repeated theme in my interviews was the importance of engaging in shared community meals and traditional activities involving the tribal government, city government, village corporation, and other ANV entities, which can build bonding social capital. This is a strategy that an ANV can engage in with little to no outside support. A community leader could facilitate a discussion during such a traditional activity that could lead to a shared planning vision. This could then form the basis for a community plan. Traditional community activities such as culture camps and sled dog races or even church groups could also be venues for fostering young leaders, rather than relying on some sort of outside training to build leadership capacity.

An example of an activity designed to build connections is the Ahtna Search Conference, a 2.5day event organized by tribes in the Ahtna region of Alaska to develop goals and strategies, overcome conflicts, and address important issues[74]. One of my research participants who also participated in that process said that, althoughsuch a traditional planning model could not be fully implemented in today's world, it did allow the Ahtna Native Corporation to enter into a collaborative agreement with the Department of the Interior for managing subsistence [75]. In other words, the traditional planning process was able to generate a common vision that galvanized cooperation with an external entity.

Another example may be the guiding principles that the Newtok Council passed to govern its relocation (mentioned in its 2011 relocation plan), which emphasized the importance of Yupik cultural values that foster togetherness. While the Newtok relocation was significantly delayed due to a community dispute and change in governance, the current tribal council and corporation have emphasized the importance of these values and have made an effort to avoid disputes that could further delay the move.

External entities can support traditional activities that build bonding social capital. For example, federal and state agencies have sponsored ANV culture camps. This investment, if supported by the community, could not only foster connections, but also build "cultural capital" that contributes to resilience[45, 48, 76].External entities could also offer mediation to help communities with internal struggles work out their differences. This would have to be a process initiated by a community that desires mediation (not by an external entity), involving a mediator supported by all parts of the community. 


\subsection{Improving External Entity Efforts to Collaborate}

A repeated theme in my interviews was that outside decision-makers and planners should spend more time in communities, rather than hoping that social capital will blossom during a single public planning meeting. In my own experience as a planner and lawyer, I have been a part of many meetings where a large number of representatives from an outside entity took a charter flight into an ANV and stayed only for a three-hour public meeting, leaving questions and concerns of ANV residents unaddressed. A better use of money could be for just one or two representatives to take a commercial flight into the ANV and stay for a few days, holding a public meeting as well as spending time in people's homes.

Another repeated theme was the apparent disregard of community and traditional knowledge by outside entities. This knowledge should merit more consideration in HMPs and other plans, where community information can be fairly generic. Bringing in community knowledge could make plans more specific to communities and increase the likelihood of community members reading them.

Finally, external entities could better support ANVs by providing mentoring and training to community members who are willing to lead planning processes. For example, Native non-profits could train young people to interview elders and go door to door to administer surveys regarding resident needs and values. Rather than hiring consultants to crank out HMPs in batches based on teleconferences and newsletters, the State of Alaska Division of Homeland Security could consider hiring a planning consultant to mentor community-based planners. While it may not be feasible for every small ANV to have its own planner, it is possible that several ANVs could share a planner or at least a person from an ANV could be part of the state agency staff responsible for these plans. It is important to provide ANV leadership with enough training on the nature and purpose of a planning process so that the ANV can meaningfully vet and amend a consultant-prepared plan. Otherwise, an ANV council's approval of a plan that it may not have even read amounts to token participation. The resulting plan, passed without meaningful community input, may never be implemented [77, 78, 79].

\subsection{Limitations of this Research}

My suggestions to external entities and planners for creating plans that are better tailored toward community needs and values are easier said than done for several reasons. First, external entities may have limited budgets and limited time to spend ensuring that all of a community's voices are heard. Second, those who fund plans (particularly HMPs) may have narrow visions of what the plans should look like, such that a planner has little room for variation. Third, some communities may have little interest in developing a robust plan - they may want a HMP for the sole purpose of getting funding under 44 C.F.R.\$201.6 (a)(1) for hazard mitigation actions (even if such actions may not be the most needed adaptation for the community in question). These limitations increase the importance of the relatively low-cost strategies that can be taken by both ANVs and external entities, such as coordinating around a community meal and engaging in frequent communication by phone.

A limitation of the overall research design was its aim to get a statewide perspective of adaptation and natural hazard planning. The design did not lend itself to participatory research involving the co-production of knowledge. Future research could build on this exploratory research to test the extent to which it applies to specific villages and involve those villages in the research process. Further, the interview questions focused on the utility of planning and the success of adaptation strategies, rather than seeking out into obstacles related to social capital. Future research could involve interviews or forums that focus more specifically on the relationship between strong social capital and successful planning. 


\section{Conclusion}

Even while some outside planners see the process of planning as helpful to ANVs, the current process is not translating traditional means of indigenous planning into planning documents that serve the ANV needs. Plans are initiated and made by outsiders without a great deal of input from ANVs. Planning often fails to reflect the whole community's needs, knowledge, and values. To the extent ANV plans are implemented, implementation may be on the terms of those outsiders. This perpetuates the history of poor communication and collaboration between ANVs and external entities with responsibility for decision-making relevant to ANVs.

Both those within ANVs and those outside can take steps to build connections that will facilitate collaboration. Within ANVs, leaders can facilitate collective action by bringing community members together around traditional meals and activities. Outside entities and planners should recognize the importance of traditional meals and activities and incorporate climate change planning into collaborations that have already withstood the test of time. Building connections is not an event, but an ongoing process that can facilitate the creation of climate change adaptation plans as well as the implementation of adaptation actions.

This conclusion has implications beyond indigenous and remote communities in Alaska. Worldwide, many small and understaffed communities may rely on external planners for support with community development. While planners must grapple with limited resources, I argue that focusing on activities that foster community trust and inclusion may result in more meaningful community plans than processes that simply produce detailed documents.

\section{FUNDING}

This work was made possible by a grant from the National Oceanic and Atmospheric Administration Sectoral Applications Research Program (NA16OAR4310122). The funder had no role in research design, data collection and analysis, writing this article, or in submitting the article for publication.

\section{REFERENCES}

[1] Hibbard, M., M. B. Lane, and K. Rasmussen. 2008. "The Split Personality of Planning: Indigenous Peoples and Planning for Land and Resource Management.” Journal of Planning Literature 23 (2): 136-151. https://doi.org/10.1177/0885412208322922.

[2] Lane, Marcus B. 2003. "Participation, Decentralization, and Civil Society: Indigenous Rights and Democracy in Environmental Planning.” Journal of Planning Education and Research 22 (4): 360-73. https://doi.org/10.1177/0739456X03022004003.

[3] Sandercock, Leonie. 2004. "Interface, Planning and Indigenous Communities.” Planning Theory \& Practice 5 (1): 95-124. https://doi.org/10.1080/1464935042000185080.

[4] Matunga, Hirini. 2013. “Theorizing Indigenous Planning.” In Reclaiming Indigenous Planning, edited by Ryan Walker, Theodore S Jojola, and David C. Natcher, 3-34. McGill-Queen's Native and Northern Series ; 70. Montreal: McGill-Queen's University Press. http://hccproxy.lib.hawaii.edu:2048/login?url=http://site.ebrary.com/lib/honcclib/Doc?id=10740369.

[5] Porter, Libby. 2010. Unlearning the Colonial Cultures of Planning. Farnham, Surrey ; Burlington, VT: Ashgate PubCo. 
Civil Engineering and Urban Planning: An International Journal (CiVEJ) Vol.5, No.2/3/4, December 2018

[6] Ostrom, Elinor. 2004. "Collective Action and Property Rights for Sustainable Development." Understanding Collective Action 2020.

http://www.unigaia-brasil.org/pdfs/Resiliencia/focus11_02.pdf.

[7] Mannell, Laura, Frank Palermo, and Crispin Smith. 2013. "Community-Based and Comprehensive: Reflections on Planning and Action in First Nations." In Reclaiming Indigenous Planning, edited by Ryan Walker, Theodore S Jojola, and David C. Natcher, 113-40. McGill-Queen's Native and Northern Series; 70. Montreal: McGill-Queen's University Press. http://hccproxy.lib.hawaii.edu:2048/login?url=http://site.ebrary.com/lib/honcclib/Doc?id=10740369.

[8] Ford, James D., Ellie Stephenson, Ashlee Cunsolo Willox, Victoria Edge, Khosrow Farahbakhsh, Christopher Furgal, Sherilee Harper, et al. 2016. "Community-Based Adaptation Research in the Canadian Arctic: Community-Based Adaptation Research.” Wiley Interdisciplinary Reviews: Climate Change 7 (2): 175-91. https://doi.org/10.1002/wcc.376.

[9] Jojola, Ted. 2008. "Indigenous Planning--an Emerging Context.(Report)." Canadian Journal of Urban Research 17 (1): 37.

[10] Lane, M. B., and M. Hibbard. 2005. "Doing It for Themselves: Transformative Planning by Indigenous Peoples." Journal of Planning Education and Research 25 (2): 172-184. https://doi.org/10.1177/0739456X05278983.

[11] Stoyanova, Irina L. 2013. "The Saami Facing the Impacts of Global Climate Change." In Climate Change and Indigenous Peoples: The Search for Legal Remedies, edited by Randall S. Abate and Elizabeth Ann Kronk Warner, 287-312. Edward Elgar Pub. http://papers.ssrn.com/sol3/papers.cfm?abstract_id=2213506.

[12] Wildcat, Daniel R. 2013. "Introduction: Climate Change and Indigenous Peoples of the USA." Climatic Change 120 (3): 509-15. https://doi.org/10.1007/s10584-013-0849-6.

[13] Ford, James D., Tristan Pearce, Frank Duerden, Chris Furgal, and Barry Smit. 2010. "Climate Change Policy Responses for Canada's Inuit Population: The Importance of and Opportunities for Adaptation." Global Environmental Change $20 \quad$ (1): 177-91. https://doi.org/10.1016/j.gloenvcha.2009.10.008.

[14] Chapin, F. Stuart, Sarah F. Trainor, Carl Markon, and Mark Serreze. 2014. "Alaska.” Climate Change Impacts in the United States: The Third National Climate Assessment, 514-36.

[15] Field, C.B., V.R. Barros, D.J. Dokken, K.J. Mach, M.D. Mastrandrea, T.E. Bilir, M. Chatterjee, et al., eds. 2014. Climate Change 2014: Impacts, Adaptation, and Vulnerability, Contribution of Working Group II to the Fifth Assessment Report of the Intergovernmental Panel on Climate Change. Cambridge, United Kingdom and New York, NY, USA: Cambridge University Press.

[16] Ristroph, E. B. 2010. “Alaska Tribes’ Melting Subsistence Rights.” Ariz. J. Envtl. L. \& Pol’y 1: 47.

[17] Alaska Native Heritage Center. 2017. “Alaska History and Cultural Studies.” 2017. http://www.akhistorycourse.org/alaskas-cultures/alaska-native-heritage-center.

[18] Alaska Division of Community and Regional Affairs. 2018. "Community Database Online.” 2018. https://www.commerce.alaska.gov/dcra/DCRAExternal.

[19] Tongco, Maria Dolores C. 2007. "Purposive Sampling as a Tool for Informant Selection." http://scholarspace.manoa.hawaii.edu/handle/10125/227.

[20] Bernard, H. Russell, and Gery W. Ryan. 2009. Analyzing Qualitative Data: Systematic Approaches. 1 edition. Los Angeles Calif.: SAGE Publications, Inc. 
Civil Engineering and Urban Planning: An International Journal (CiVEJ) Vol.5, No.2/3/4, December 2018

[21] Jacobs, Melanie B., and Jeffery J. Brooks. 2011. "Alaska Native Peoples and Conservation Planning: A Recipe for Meaningful Participation.” Native Studies Review 20 (2): 91-135.

[22] Johnson, Terry, and Glenn Gray. 2014. "Shaktoolik, Alaska: Climate Change, Adaptation for an AtRisk Community Adaptation Plan.”

[23] Kettle, Nathan, Jacob Martin, and Michael Sloan. 2017. "Nome Tribal Climate Adaptation Plan."

[24] Cho, Ji Young, and Eun-Hee Lee. 2014. "Reducing Confusion about Grounded Theory and Qualitative Content Analysis: Similarities and Differences.(Report)." The Qualitative Report.

[25] Miles, Matthew B., and A. Michael Huberman. 1994. Qualitative Data Analysis: An Expanded Sourcebook, 2nd Edition. 2nd edition. Thousand Oaks: SAGE Publications, Inc.

[26] Bernard, H. Russell. 2006. Research Methods in Anthropology: Qualitative and Quantitative Approaches. 4th ed. Lanham, MD: AltaMira Press.

[27] Zhang, Yan, and Barbara M. Wildemuth. 2005. "Qualitative Analysis of Content By.” Analysis 1 (2): $1-12$.

[28] Ristroph, Elizaveta Barrett. 2017. "Presenting a Picture of Alaska Native Village Adaptation: A Method of Analysis." Sociology and Anthropology 5 (9): 762-75. https://doi.org/10.13189/sa.2017.050908.

[29] Margerum, Richard D. 2008. "A Typology of Collaboration Efforts in Environmental Management." Environmental Management 41 (4): 487-500. https://doi.org/10.1007/s00267-008-9067-9.

[30] Lubell, Mark, Paul A. Sabatier, Arnold Vedlitz, Will Focht, Zev Trachtenberg, and Marty Matlock. 2005. "Conclusions and Recommendations." In Swimming Upstream: Collaborative Approaches to Watershed Management, edited by Paul A. Sabatier, Will Focht, Mark Lubell, Zev Trachtenberg, Arnold Vedlitz, and Marty Matlock, 261-96. Cambridge, Mass: The MIT Press.

[31] Sabatier, Paul A., Will Focht, Mark Lubell, Zev Trachtenberg, Arnold Vedlitz, and Marty Matlock. 2005. "Collaborative Approaches to Watershed Management." In Swimming Upstream: Collaborative Approaches to Watershed Management, edited by Paul A. Sabatier, Will Focht, Mark Lubell, Zev Trachtenberg, Arnold Vedlitz, and Marty Matlock, 4-21. Cambridge, Mass: The MIT Press.

[32] Sabatier, Paul A., Chris Weible, and Jared Ficker. 2005. "Eras of Water Management in the United States: Implications for Collaborative Watershed Approaches." In Swimming Upstream: Collaborative Approaches to Watershed Management, edited by Paul A. Sabatier, Will Focht, Mark Lubell, Zev Trachtenberg, Arnold Vedlitz, and Marty Matlock, 23-52. Cambridge, Mass: The MIT Press.

[33] Focht, Will, and Zev Trachtenberg. 2005. "A Trust-Based Guide to Stakeholder Participation." In Swimming Upstream: Collaborative Approaches to Watershed Management, edited by Paul A. Sabatier, Will Focht, Mark Lubell, Zev Trachtenberg, Arnold Vedlitz, and Marty Matlock, 85-135. Cambridge, Mass: The MIT Press.

[34] Berkes, Fikret, Gary P. Kofinas, and F. Stuart Chapin III. 2009. "Conservation, Community, and Livelihoods: Sustaining, Renewing, and Adapting Cultral Connections to the Land." In Principles of Ecosystem Stewardship: Resilience-Based Natural Resource Management in a Changing World, edited by F. Stuart Chapin III, Carl Folke, and Gary P. Kofinas, 2009 edition, 129-47. New York: Springer. 
Civil Engineering and Urban Planning: An International Journal (CiVEJ) Vol.5, No.2/3/4, December 2018

[35] Kofinas, Gary P. 2009. “Adaptive Co-Management in Social-Ecological Governance.” In Principles of Ecosystem Stewardship: Resilience-Based Natural Resource Management in a Changing World, edited by F. Stuart Chapin III, Carl Folke, and Gary P. Kofinas, 2009 edition, 77-101. New York: Springer.

[36] Johnston, E. W., D. Hicks, N. Nan, and J. C. Auer. 2011. "Managing the Inclusion Process in Collaborative Governance.” Journal of Public Administration Research and Theory 21 (4): 699-721. https://doi.org/10.1093/jopart/muq045.

[37] Winer, Michael Barry, and Karen Ray. 1994. Collaboration Handbook: Creating, Sustaining, and Enjoying the Journey. 1st edition. Saint Paul, Minn: Amherst H. Wilder Foundation.

[38] Innes, J.E., J. Gruber, M. Neuman, and R. Thompson. 2011. "Coordinating Growth and Environmental Management through Consensus Building.” CPS Report: A Policy Research Program Report. Berkeley: California Policy Seminar, University of California.

[39] Innes, Judith E., and David E. Booher. 2003. "The Impact of Collaborative Planning on Governance Capacity." Institute of Urban \& Regional Development, April. http://escholarship.org/uc/item/98k72547.

[40] Healey, Patsy. 2006. Collaborative Planning, Second Edition: Shaping Places in Fragmented Societies. Second Edition edition. Basingstoke, Hampshire; New York: Palgrave Macmillan.

[41] Ansell, C., and A. Gash. 2007. "Collaborative Governance in Theory and Practice." Journal of Public Administration Research and Theory 18 (4): 543-71. https://doi.org/10.1093/jopart/mum032.

[42] Adger, W. Neil. 2003. "Social Capital, Collective Action, and Adaptation to Climate Change." Economic Geography 79 (4): 387-404.

[43] Coleman, James S. 1988. "Social Capital in the Creation of Human Capital." American Journal of Sociology 94 (January): S95-120.

[44] Putnam, Robert D., and Kristin A. Goss. 2002. "Introduction.” In Democracies in Flux the Evolution of Social Capital in Contemporary Society, edited by Robert D. Putnam, 3-19. Oxford ; New York: Oxford University Press.

[45] Arctic Council. 2017. "Adaptation Actions for a Changing Arctic (AACA)-Bering/Chukchi/Beaufort Region Overview Report.” https://oaarchive.arctic-council.org/handle/11374/1941.

[46] Norris, Fran, Susan Stevens, Betty Pfefferbaum, Karen Wyche, and Rose Pfefferbaum. 2008. "Community Resilience as a Metaphor, Theory, Set of Capacities, and Strategy for Disaster Readiness." American Journal of Community Psychology 41 (1): 127-150. https://doi.org/10.1007/s10464-007-9156-6.

[47] Western, John, Robert Stimson, Scott Baum, and Yolanda Van GELLECUM. 2005. "Measuring Community Strength and Social Capital." Regional Studies 39 (8): 1095-1109. https://doi.org/10.1080/00343400500328222.

[48] Nilsson, Annika, Grete Hovelsrud, Helene Amundsen, Tahnee Prior, and Martin Sommerkorn. 2016. "Building Capacity to Adapt to and Shape Change." In Arctic Resilience Report, edited by M Carson and G Peterson, 164-79. Stockholm: tockholm Environment Institute and Stockholm Resilience Centre.

[49] Cutter, Susan L., Lindsey Barnes, Melissa Berry, Christopher Burton, Elijah Evans, Eric Tate, and Jennifer Webb. 2008. “A Place-Based Model for Understanding Community Resilience to Natural Disasters." Global Environmental Change $18 \quad$ (4): $598-606$. https://doi.org/10.1016/j.gloenvcha.2008.07.013. 
Civil Engineering and Urban Planning: An International Journal (CiVEJ) Vol.5, No.2/3/4, December 2018

[50] Grootaert, Christiaan, and Thierry van Bastelaer, eds. 2002. Understanding and Measuring Social Capital: A Multi-Disciplinary Tool for Practitioners. Washington, D.C: World Bank Publications.

[51] Ostrom, Elinor, and T. K. Ahn. 2003. Foundations of Social Capital. Cheltenham, UK; Northhampton, MA: Edward Elgar Pub.

[52] Reid, Catherine, and Lawrence Salmen. 2002. "Qualitative Analysis of Social Capital: The Case of Agricuitural Extension in Mali." In Understanding and Measuring Social Capital: A MultiDisciplinary Tool for Practitioners, edited by Christiaan Grootaert and Thierry van Bastelaer, 85-107. Washington, D.C: World Bank Publications.

[53] Kofinas, Gary, Shauna B. BurnSilver, James Magdanz, Rhian Stotts, and Marcy Okada (2016), Subsistence Sharing Networks and Cooperation: Kaktovik, Wainwright, and Venetie, Alaska. BOEM Report 2015-023DOI; AFES Report MP 2015-02. School of Natural Resources and Extension, University of Alaska Fairbanks.

[54] McNeeley, Shannon Michele. 2009. "Seasons out of Balance: Climate Change Impacts, Vulnerability, and Sustainable Adaptation in Interior Alaska." University of Alaska Fairbanks. http://www.cakex.org/sites/default/files/project/documents/McNeeley_Dissertation_2009.pdf.

[55] Klein, Richard J. T., Guy F. Midgley, and Benjamin L. Preston. 2014. "Adaptation Opportunities, Constraints, and Limits.” In Climate Change 2014 Impacts, Adaptation, and Vulnerability Working Group II Contribution to the IPCC Fifth Assessment Report, Global and Sectoral Aspects, 1:899-944. Cambridge University Press. http://dx.doi.org/10.1017/CBO9781107415379.021.

[56] Wuttunee, Wanda. 2004. Living Rhythms: Lessons in Aboriginal Economic Resilience and Vision. Montréal ; Ithaca: Mcgill Queens Univ Pr.

[57] Ritchie, Liesel Ashley, and Duane A. Gill. 2010. "Fostering Resiliency in Renewable Resource Communities Subsistence Lifescapes and Social Capital." In How Ethnically Marginalized Americans Cope with Catastrophic Disasters, edited by Jason D Rivera and DeMond S Miller, 51-82. The Edwin Mellen Press. http://www.ebooks.com/1047222/how-ethnically-marginalized-americanscope-with-catastrophic-disasters/rivera-jason-d-ed--miller-demond-s-ed/.

[58] Garmestani, Ahjond S., and Melinda Harm Benson. 2013. "A Framework for Resilience-Based Governance of Social-Ecological Systems.” Ecology and Society 18 (1). https://doi.org/10.5751/ES05180-180109.

[59] Olsson, Per, Carl Folke, and Fikret Berkes. 2004. "Adaptive Comanagement for Building Resilience in Social?Ecological Systems." Environmental Management 34 (1). https://doi.org/10.1007/s00267003-0101-7.

[60] Minerbi, Luciano. 2003. "Cultural Assessments and the Planning Process." American Planning Association.

[61] Chapin, F Stuart, Corrine N Knapp, Todd J Brinkman, Robin Bronen, and Patricia Cochran. 2016. "Community-Empowered Adaptation for Self-Reliance." Current Opinion in Environmental Sustainability 19 (April): 67-75. https://doi.org/10.1016/j.cosust.2015.12.008.

[62] Adger, W. Neil, Jon Barnett, Katrina Brown, Nadine Marshall, and Karen O'Brien. 2012. "Cultural Dimensions of Climate Change Impacts and Adaptation." Nature Climate Change 3 (2): 112-17. https://doi.org/10.1038/nclimate1666. 
Civil Engineering and Urban Planning: An International Journal (CiVEJ) Vol.5, No.2/3/4, December 2018

[63] Hardess, Lisa. 2013. "Co-Creative Planning: Simpcw First Nation and the Centre for Indigenous Environmental Resources." In Reclaiming Indigenous Planning, edited by Ryan Walker, Theodore S Jojola, and David C. Natcher, 141-65. McGill-Queen's Native and Northern Series ; 70. Montreal: McGill-Queen's University Press. http://hccproxy.lib.hawaii.edu:2048/login?url=http://site.ebrary.com/lib/honcclib/Doc?id=10740369.

[64] Pearce, Tristan, James D. Ford, Amanda Caron, and Bill Patrick Kudlak. 2012. "Climate Change Adaptation Planning in Remote, Resource-Dependent Communities: An Arctic Example.” Regional Environmental Change 12 (4): 825-37. https://doi.org/10.1007/s10113-012-0297-2.

[65] Brunner, Ronald D., and Amanda H. Lynch. 2010. Adaptive Governance and Climate Change. American Meteorological Society.

[66] Gray, Glenn. 2010. “Kivalina Consensus Building Project, Final Project Report.” Glenn Gray and Associates.

[67] DeMarban, Alex. 2015. "Interior Secretary Vows to Work on Solutions for Climate-Threatened Village." Alaska Dispatch, February 16, 2015. http://www.adn.com/article/20150216/interiorsecretary-vows-work-solutions-climate-threatened-village.

[68] Demer, Lisa. 2015. "The Creep of Climate Change." Alaska Dispatch, August 29, 2015. http://www.adn.com/article/20150829/creep-climate-change.

[69] Chapin, F. Stuart, and Patricia Cochran. 2014. "Community Partnership for Self Reliance and Sustainability, Final Report to Communities from the Alaska Native Science Commission and the University of Alaska Fairbanks."

[70] Chaffee, Eric. 2008. "Business Organizations and Tribal Self-Determination: A Critical Reexamination of the Alaska Native Claims Settlement Act." Alaska Law Review 25 (1): 107-55.

[71] Knapp, Corrine N., F. Stuart Chapin III, Gary P. Kofinas, Nancy Fresco, Courtney Carothers, and Amy Craver. 2014. "Parks, People, and Change: The Importance of Multistakeholder Engagement in Adaptation Planning for Conserved Areas.” Ecology and Society 19 (4): 16.

[72] Stewart, Brooke C., Kenneth E. Kunkel, Laura E. Stevens, Sun Liqiang, and John Walsh. 2013. "Regional Climate Trends and Scenarios for the U.S. National Climate Assessment, Part 7, Climate of Alaska." NOAA Technical Report NEDIS 142-7. http://www. nesdis.noaa.gov/technical_reports/NOAA_NESDIS_Tech_Report_142-7-Climate_of_Alaska.pdf.

[73] Ristroph, E. B. 2018. "Improving the quality of Alaska Native village climatechange planning." Journal of Geography and Regional Planning.

[74] Innovative Solutions. 2011. "Ahtna Planning Conference Report."

[75] Department of the Interior and Ahtna. 2016. "Memorandum of Agreement between U.S. Department of the Interior and Ahtna Inter-Tribal Resource Commission for a Demonstration Project for the Cooperative Management of Customary and Traditional Subsistence Uses in the Ahtna Region."

[76] Ford, James, Tristan Pearce, Barry Smit, Johanna Wandel, Mishak Allurut, Kik Shappa, Harry Ittusujurat, and Kevin Qrunnut. 2007. "Reducing Vulnerability to Climate Change in the Arctic: The Case of Nunavut, Canada.” Arctic, 150-166.

[77] Buchiri, Noora, Bader Al Mannai and Saad M. A. Suliman.2017. "Incorporating Participatory Planning and Quality Function Deployment in Urban Planning." Civil Engineering and Urban Planning, 4(1): 1-13.

[78] Frazier, T.G. et al. 2013. "Opportunities and constraints tohazard mitigationplanning.”AppliedGeography40: 52-60.

[79] Stults, Missy. 2017. Integrating climate change into hazard mitigation planning:Opportunities and examples in practice. Climate Risk Management17: 21-34. 